\title{
Incidental cleaning of crinoids by juveniles of Bodianus anthioides (Bennett, 1831) (Labridae) in the Red Sea
}

Received: 9 February 2009/Accepted: 25 May 2009/Published online: 16 June 2009

(C) Springer-Verlag 2009
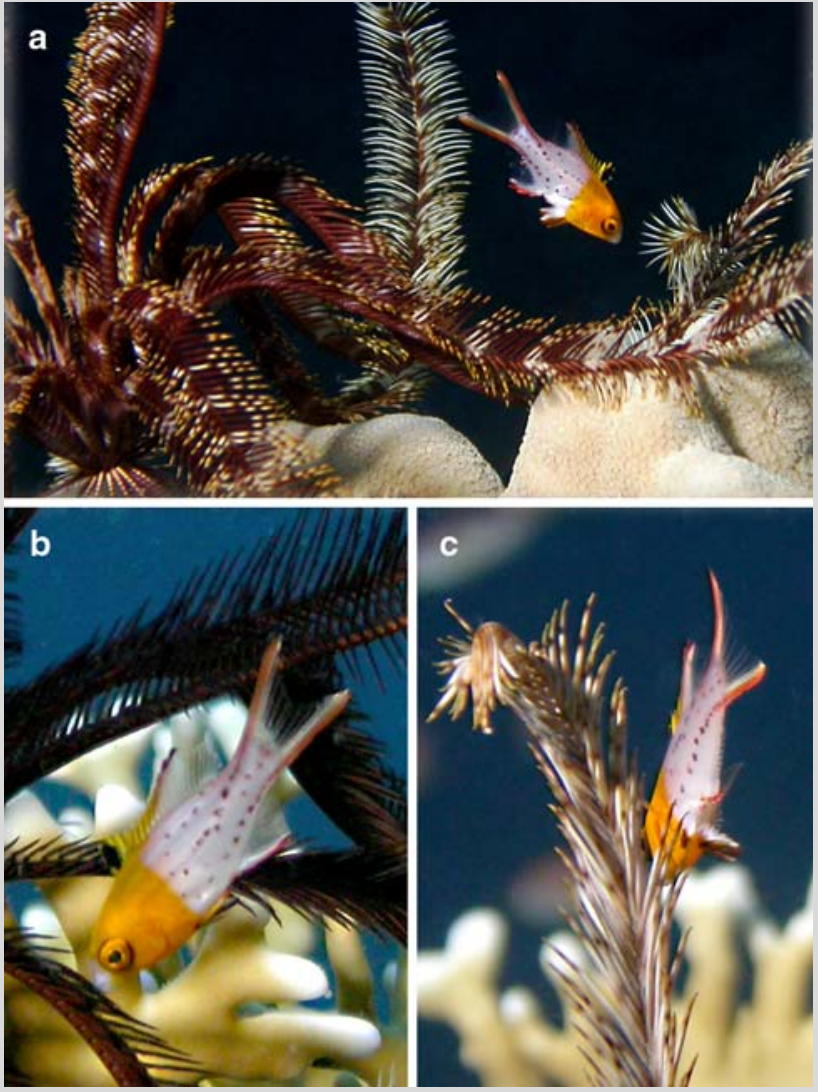

Fig. 1 The juvenile of B. anthioides cleaning two specimens of $L$. kluzingeri a The fish targeting the prey. b-c The fish nibbling at the inner and outer side of the pinnules, respectively (Red Sea, September, 2007)
The fish family Labridae consists of over 500 species, several of which are obligate or facultative cleaners that remove parasites from their hosts, generally other fishes (Wilson and Wilson 1985), but rarely also from invertebrates. This paper reports on the cleaning activity of juveniles of Bodianus anthioides (Bennett, 1831) on crinoids in the Red Sea. During a dive undertaken at dusk, at Marsa Shagra (20 Km north of Marsa Alam, Red Sea, Egypt), the emergence of three specimens of the crinoid Lamprometra kluzingeri (Hartlaub, 1890) which left their daytime shelters to occupy nocturnal perches and collect plankton (Rutman and Fishelson 1969) was observed. As soon as they stabilized on the top of coral colonies, a juvenile of B. anthioides approached the crinoids and started a close inspection of their arms (Fig. 1a). The fish moved around the crinoids repeatedly, for about 3 minutes, removing several undetermined food items from each side of the arms' pinnules (Fig. 1b-c). During this activity, crinoids did not react to the fish. B. anthioides is a common Indo-Pacific reef fish (Gomon 2006), and it has been observed in the Red Sea that juveniles of this species can serve as facultative fish cleaners (Bshary 2003). The present observation suggests that juveniles of this species may also integrate their diet opportunistically by targeting crinoids, which may host several other invertebrates, especially copepods (Fishelson 1974). As crinoids were involuntary 'clients', and no injury to their arms was observed, this kind of cleaning symbiosis can reasonably be considered as an example of incidental cleaning (Côté 2000). Although, the nature of the removed food item is unknown, it is however possible to exclude both kleptocommensal or commensal behaviour of $B$. anthioides for several reasons. Firstly, due to the mismatch between the diel activity patterns of the two species, Labridae typically being diurnal (Helfman et al 1997) and crinoids nocturnal. In addition, the crinoids had just emerged and had not started yet to collect food. Other evidence lies in the fact that some items were removed by the fish from the external side of the pinnules (Fig. 1c), where no food is concentrated by crinoids and, more generally, by the fact that planktonic food has never been recorded in B. anthioides gut content analysis (Gomon 2006). The behaviour we observed therefore suggests not a stable partnership, but rather an opportunistic one which may occur during the twilight changeover (Helfman et al. 1997), when diel activities the two partners overlap for some minutes.

\section{References}

Bshary R (2003) The cleaner wrasse, Labroides dimidiatus, is a key organism for reef fish diversity at Ras Mohammed National Park, Egypt. J Anim Ecol 72:169-176 Côté IM (2000) Evolution and ecology of cleaning symbioses in the sea. Oceanogr Mar Biol Annu Rev 38:311-355

Fishelson L (1974) Ecology of the Northern Red Sea crinoids and their epi- and endozoic fauna. Mar Biol 26:183-192

Gomon MF (2006) A revision of the labrid fish genus Bodianus with descriptions of eight new species. Rec Austr Mus 30:1-133

Helfman GS, Collette BB, Facey DE (1997) The diversity of fishes. Blackwell, Oxford

Rutman J, Fishelson L (1969) Food composition and feeding behaviour of shallow-water crinoids at Eilat (Red Sea). Mar Biol 3:46-57

Wilson R, Wilson JQ (1985) Watching fishes: life and behavior on coral reefs. Harper and Row, New York, 275 pp

S. Schiaparelli $(\bowtie) \cdot$ M. C. Alvaro

Dipartimento per lo Studio del Territorio e delle sue Risorse (Dip.Te.Ris.), Università di Genova, C.so Europa 26, 16132 Genoa, Italy e-mail: steschia@dipteris.unige.it 